\title{
Dampak output GDP sektor pertanian terhadap masalah pembangunan ekonomi di Indonesia (kemiskinan dan pengangguran)
}

\author{
Candra Mustika*; Emilia \\ Prodi Ekonomi Pembangunan Fakultas Ekonomi dan Bisnis Universitas Jambi \\ *E-mail korespondensi: bluemickeyid@yahoo.com
}

\begin{abstract}
This study aims to analyze the development of agricultural GDP output and poverty and unemployment during the period 1993 - 2014 and analyze the effect of the GDP Output of the agricultural sector on the level of poverty and unemployment in Indonesia in that period. The results showed that during the period of 1993-2014 the data on gross domestic product (GDP) originating from the agricultural sector continued to fluctuate in the increase and decrease, the average GDP value of the agricultural sector is 496.9 trillion with an average value of $17 \%$. The regression results in the first model show that agricultural sector GDP does not have a significant effect on poverty and the regression results in the second model show that agricultural GDP does not have a significant effect on the number of unemployed people in Indonesia.
\end{abstract}

Keywords: Agricultural Sector GDP, Poverty, Unemployment

\begin{abstract}
Abstrak
Penelitian ini bertujuan untuk menganalisis perkembangan Output GDP sektor pertanian dan kemiskinan serta pengangguran selama periode tahun 1993 - 2014 dan menganalisis dampak Output GDP Sektor pertanian tersebut terhadap tingkat kemiskinan dan pengangguran di Indonesia pada periode tersebut. Hasil penelitian menunjukkan Selama periode tahun 1993-2014 data produk domestik bruto (GDP) yang berasal dari sektor pertanian terus mengalami fluktuasi kenaikan dan penurunan, rata-rata nilai GDP output sektor pertanian adalah 496,9 triliun dengan nilai rata-rata sebesar 17\%. Hasil regresi pada model pertama menunjukkan bahwa GDP sektor pertanian tidak berpengaruh signifikan terhadap kemiskinan dan hasil regresi pada model kedua menunjukkan bahwa GDP sektor pertanian tidak berpengaruh signifikan terhadapa jumlah pengangguran di Indonesia.
\end{abstract}

Kata Kunci : GDP Sektor pertanian, Kemiskinan, Pengangguran

\section{PENDAHULUAN}

Indonesia merupakan Negara yang kaya akan sumber daya alam baik sumber daya alam yang tidak dapat diperbarui seperti hasil tambang minyak dan gas serta barangbarang mineral batubara maupun sumber daya alam yang dapat diperbarui seperti hasilhasil dari ternak hewan dan tumbuh-tumbuhan yang terdapat di darat maupun di laut, oleh sebab itulah dengan modal sumber daya alam tersebut Indonesia termasuk Negara yang menghasilkan berbagai komoditas yang dibutuhkan oleh dunia internasional terutama hasil-hasil dari sektor pertanian seperti padi,kelapa sawit,karet,teh,kopi dan lain-lainnya sehingga kontribusi sektor pertanian ke pendapatan nasional Indonesia cukup besar, Hal ini dapat dilihat dari data Produk Domestik Bruto (PDB atau GDP) Indonesia yang sumbangan sektor pertanian masih relatif tinggi pada tahun 2013 nilai sektor pertanian sebesar 1.083,1 Triliun rupiah dari total GDP Indonesia sebesar 8.158,2 
Triliun Rupiah (Sumber ADB) dan Jumlah tenaga kerja yang bekerja di sektor ini yang paling banyak dengan data menunjukkan pada tahun 2013 jumlah tenaga kerja yang bekerja di sektor pertanian adalah 39,220 dalam ribuan jiwa sehingga diharapkan sektor pertanian ini dapat mewujudkan dan mendukung pembangunan ekonomi.

Pembangunan ekonomi salah satu tujuannya adalah mewujudkan masyarakat yang adil dan makmur sehingga salah satu indikatornya adalah untuk mengatasi masalahmasalah kemiskinan dan pengangguran yang dapat mengurangi tingkat kemakmuran suatu Negara. Berdasarkan uraian pada latar belakang diataslah yang melatar belakangi penulis untuk menganalisis GDP sektor pertanian dan dampaknya terhadap pembangunan ekonomi (Mengurangi kemiskinan dan Pengangguran). Secara spesifik perumusan permasalahan penilitian ini adalah bagaimanakah perkembangan GDP output sektor pertanian, dan tingkat pengangguran dan kemiskinan di Indonesia selama periode tahun 1993 sampai 2014, bagaimana pengaruh GDP output sektor pertanian terhadap tingkat pengangguran di Indonesia selama periode tahun 1993 sampai 2014, dan bagaimana pengaruh GDP output sektor pertanian terhadap tingkat kemiskinan di Indonesia selama periode tahun 1993 sampai 2014.

\section{METODE}

\section{Metode Analisis}

Dalam menganalisa data-data yang diperoleh untuk menjawab tujuan dari penelitian ini, maka digunakan metode-metode analisa sebagai berikut:

Analisis Deskriptif

Merupakan analisis yang dilakukan secara deskriptif untuk memberikan gambaran mengenai perkembangan Variabel-variabel Penelitian, digunakan formula :

$$
\text { Igt }=\frac{\text { It }- \text { It-1 }}{\text { It-1 }} \times 100 \%
$$

Dimana:

Igt $\quad$ = Perkembangan Variabel-variabel Penelitian (Pendapatan perkapita,FDI dan Nilai ekspor ke jepang))

It $\quad=$ Variabel Penelitian tahun $\mathrm{t}$

It-1 = Variabel Penelitian tahun $\mathrm{t}-1$

Analisis Kuantitatif

Kemudian untuk menganalisis pengaruh nilai ekspor ke jepang terhadap pendapatan perkapita Indonesia digunakan regresi sederhana sebagai berikut :

$$
\mathbf{Y p}=\boldsymbol{\beta} \mathbf{0}++\boldsymbol{\beta}_{\mathbf{1}} \mathbf{X} \mathbf{j}++\mathbf{e}
$$

Kemudian untuk menganalisis pengaruh FDI terhadap pendapatan perkapita Indonesia digunakan regresi sederhana sebagai berikut :

$\begin{array}{lll} & \mathbf{Y p}=\boldsymbol{\beta} \mathbf{c}+\boldsymbol{\beta}_{\mathbf{1}} \mathbf{F D I} \quad+\mathbf{e} \\ \mathrm{Yp} & : & \text { Pendapatan perkapita } \\ \mathrm{Xm} & : & \text { Nilai Ekspor ke Jepang } \\ \mathrm{FDI} & : & \text { Investasi asing langsung } \\ \mathrm{t} & : & \text { Tahun 1993 sampai 2014 } \\ \beta_{0} & : & \text { Konstanta } \\ \beta_{1} & : & \text { Koefisien Regresi Variabel Independen } \\ \varepsilon & : & \text { Error term }\end{array}$




\section{HASIL DAN PEMBAHASAN}

\section{Perkembangan GDP output sektor pertanian Indonesia}

Untuk mengetahui perkembangan GDP output sektor pertanian selama periode tahun 1993 sampai 2014 dapat dilihat pada tabel berikut ini :

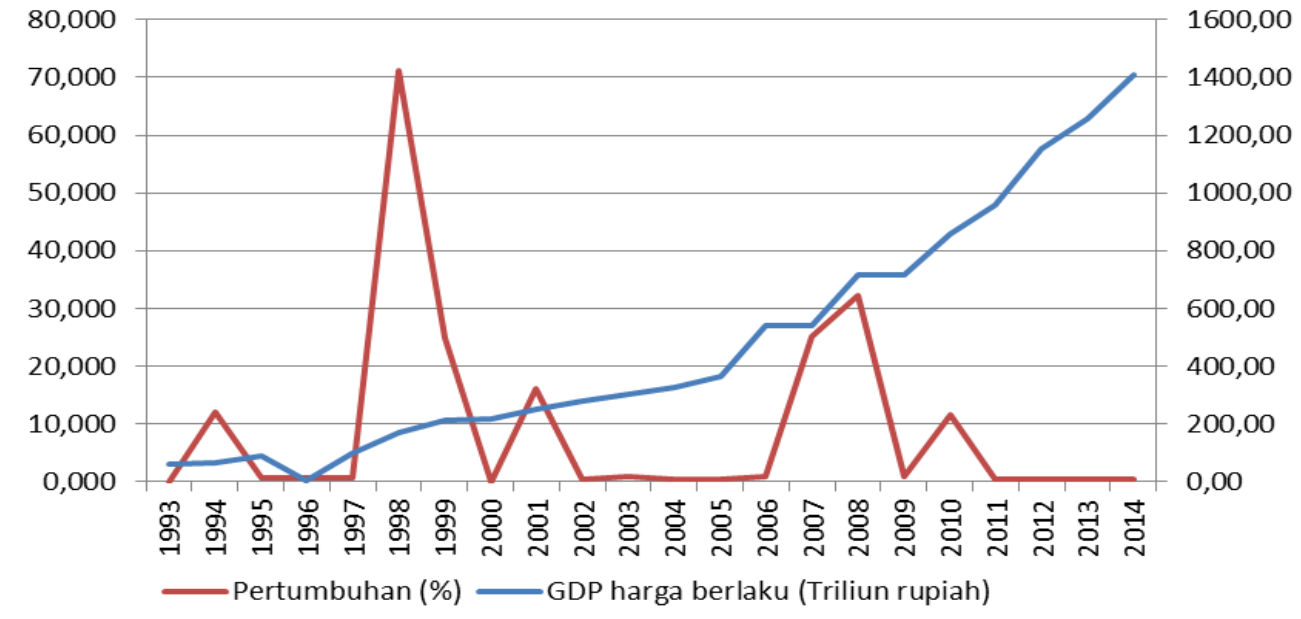

Sumber : ADB (Asian Development Bank)

Gambar 1. Perkembangan GDP Output sektor pertanian Indonesia 1993-2014

Dari Gambar.1 terlihat bahwa dari awal periode tahun 1993 sampai tahun 2014 data produk domestik bruto (GDP) yang berasal dari sektor pertanian terus mengalami fluktuasi kenaikan dan penurunan, rata-rata nilai GDP output sektor pertanian adalah 496,9 triliun dengan nilai rata-rata sebesar 17\%, pada periode tersebut tingkat pertumbuhan tertinggi terjadi pada tahun 1998 yakni 71,08\% dan pertumbuhan terendah terjadi pada tahun 2000 yakni sebesar $0,50 \%$.

\section{Perkembangan kemiskinan di Indonesia}

Untuk mengetahui keadaan penduduk miskin Indonesia selama periode tahun 1993-2014 dapat dilihat pada tabel berikut ini :

Sumber : BPS

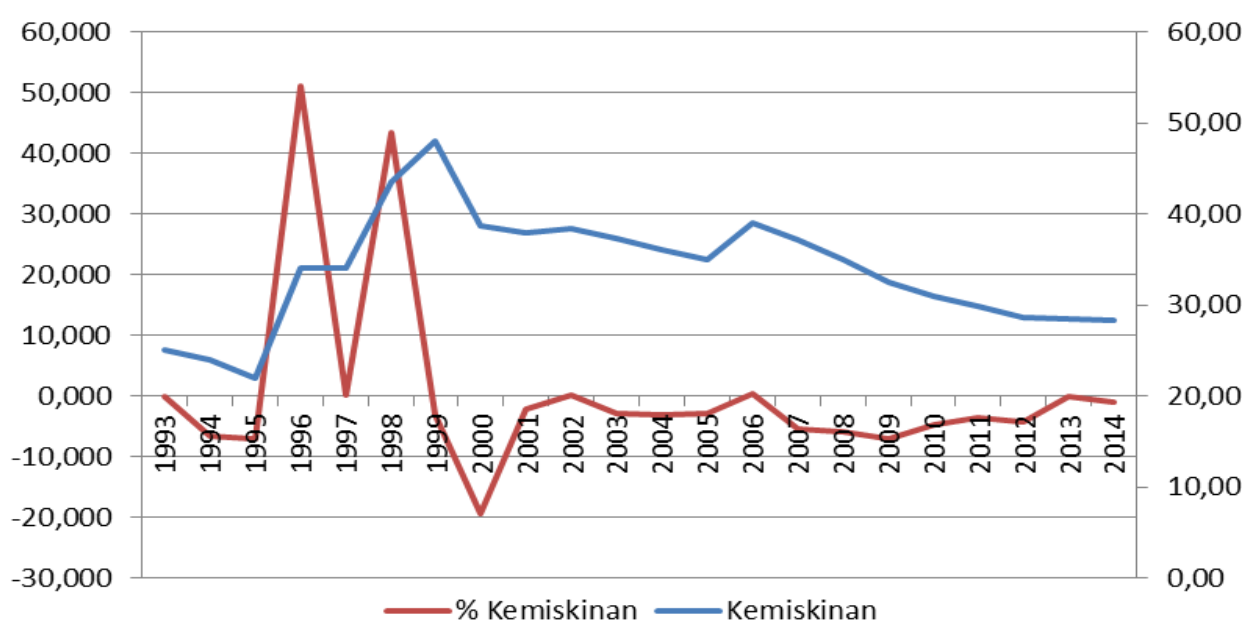

Gambar 2. Perkembangan jumlah penduduk miskin Indonesia 1993-2014 
Dari Gambar. 2 terlihat bahwa selama periode tahun 1993-2014 jumlah penduduk miskin Indonesia mengalami fluktuasi naik turun dengan rata-rata jumlahnya 34,2 juta jiwa dan rata-rata pertumbuhannya $1,44 \%$, selama periode tersebut pertumbuhan tertinggi terjadi pada tahun 1996 yakni 51,15\% dan pertumbuhan terendah terjadi pada tahun 2000 yakni $-19,24 \%$.

\section{Perkembangan pengangguran di Indonesia}

Untuk mengetahui jumlah pengangguran yang ada di Indonesia dapat dilihat pada tabel berikut ini :

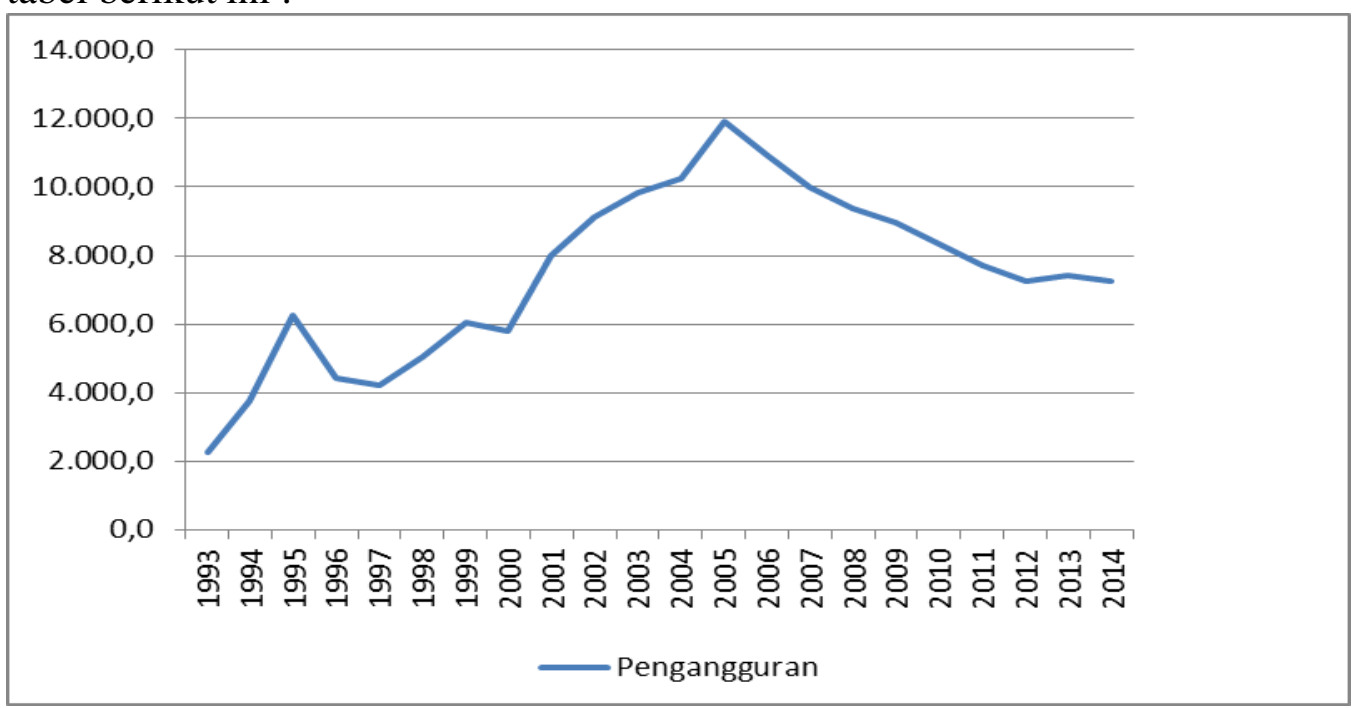

Sumber : ADB (Asian Development Bank)

Gambar 3 Jumlah pengangguran di Indonesia 1993-2014

Dari Gambar. 3 terlihat bahwa selama periode penelitian dari tahun 1993-2014 jumlah pengangguran di indonesia mengalami fluktuasi atau naik turun dengan rata-rata nilainya sebesar 7.457,95 dalam ribu jiwa dengan rata-rata pertumbuhan 7,97\%, selama periode tersebut dapat diperoleh informasi pertumbuhan terendah terjadi pada tahun 1996 yakni -29,48\% dan pertumbuhan tertinggi terjadi pada tahun 1995 yakni 67,22\%.

\section{Pengaruh GDP sektor pertanian terhadap jumlah penduduk miskin}

Untuk mengetahui pengaruh GDP sektor pertanian terhadap jumlah penduduk miskin dapat dilihat pada tabel berikut ini:

Tabel 1 Hasil regresi GDP pertanian dan kemiskinan

\begin{tabular}{lrllr}
\hline \multicolumn{1}{c}{ Variable } & Coefficient & Std. Error & t-Statistic & \multicolumn{1}{c}{ Prob. } \\
\hline C & 36.50886 & 2.182478 & 16.72817 & 0.0000 \\
GDPP & -0.004641 & 0.003350 & -1.385542 & 0.1811 \\
R-squared & 0.087580 & Mean dependent var & 34.20273 \\
Adjusted R-squared & 0.041959 & S.D. dependent var & 6.764911 \\
S.E. of regression & 6.621466 & Akaike info criterion & 6.705019 \\
Sum squared resid & 876.8763 & Schwarz criterion & 6.804204 \\
Log likelihood & -71.75521 & F-statistic & 1.919726 \\
Durbin-Watson stat & 0.565717 & Prob(F-statistic) & 0.181145 \\
\hline
\end{tabular}

Sumber: Data diolah, 2017

Berdasarkan hasil regresi pada Tabel.1 terlihat bahwa GDP pertanian tidak berpengaruh signifikan terhadap kemiskinan hal ini diperoleh berdasarkan hasil uji thitung 
diperoleh nilai t hitung sebesar -1,38 dengan probabilitas 0,18 melebihi tingkat batas signifikansi alpha $10 \%$, sehingga tidak perlu dibuat persamaan regresinya.

\section{Pengaruh GDP Sektor Pertanian terhadap pengangguran}

Untuk mengetahui pengaruh GDP sektor Pertanian terhadap jumlah pengangguran dapat dilihat pada tabel berikut ini :

Tabel 2 Hasil regresi GDP sektor pertanian dan pengangguran

\begin{tabular}{lrllr}
\hline \multicolumn{1}{c}{ Variable } & Coefficient & Std. Error & t-Statistic & \multicolumn{1}{c}{ Prob. } \\
\hline \multicolumn{1}{c}{ C } & 6493.641 & 806.9065 & 8.047575 & 0.0000 \\
GDPP & 1.940660 & 1.238421 & 1.567043 & 0.1328 \\
R-squared & 0.109355 & Mean dependent var & 7457.955 \\
Adjusted R-squared & 0.064822 & S.D. dependent var & 2531.515 \\
S.E. of regression & 2448.091 & Akaike info criterion & 18.53051 \\
Sum squared resid & $1.20 \mathrm{E}+08$ & Schwarz criterion & 18.62970 \\
Log likelihood & -201.8356 & F-statistic & 2.455624 \\
Durbin-Watson stat & 0.232339 & Prob(F-statistic) & 0.132791 \\
\hline
\end{tabular}

Sumber: Data diolah, 2017

Berdasarkan dari informasi Tabel. 2 diperoleh nilai t hitung sebesar 1,56 dengan probabilitas 0,13 melebihi batas toleransi signifikansi alpha 10\% dengan demikian diperoleh kesimpulan bahwa GDP sektor pertanian tidak berpengaruh signifikan terhadap jumlah pengangguran di Indonesia .

\section{KESIMPULAN DAN SARAN}

\section{Kesimpulan}

Adapun kesimpulan yang dapat diperoleh dalam penelitian ini adalah pada periode tahun 1993 sampai tahun 2014 data produk domestik bruto (GDP) yang berasal dari sektor pertanian terus mengalami fluktuasi kenaikan dan penurunan, rata-rata nilai GDP output sektor pertanian adalah 496,9 triliun dengan nilai rata-rata sebesar $17 \%$, pada periode tersebut tingkat pertumbuhan tertinggi terjadi pada tahun 1998 yakni 71,08\% dan pertumbuhan terendah terjadi pada tahun 2000 yakni sebesar $0,50 \%$. jumlah penduduk miskin Indonesia mengalami fluktuasi naik turun dengan rata-rata jumlahnya 34,2 juta jiwa dan rata-rata pertumbuhannya $1,44 \%$, selama periode tersebut pertumbuhan tertinggi terjadi pada tahun 1996 yakni 51,15\% dan pertumbuhan terendah terjadi pada tahun 2000 yakni $-19,24 \%$. jumlah pengangguran di indonesia mengalami fluktuasi atau naik turun dengan rata-rata nilainya sebesar 7.457,95 dalam ribu jiwa dengan rata-rata pertumbuhan $7,97 \%$, selama periode tersebut dapat diperoleh informasi pertumbuhan terendah terjadi pada tahun 1996 yakni -29,48\% dan pertumbuhan tertinggi terjadi pada tahun 1995 yakni $67,22 \%$. Hasil regresi pada model pertama menunjukkan bahwa GDP sektor pertanian tidak berpengaruh signifikan terhadap kemiskinan dan hasil regresi pada model kedua menunjukkan bahwa GDP sektor pertanian tidak berpengaruh signifikan terhadapa jumlah pengangguran di Indonesia.

\section{Saran}

Kemiskinan dan pengangguran masih merupakan masalah makro ekonomi yang harus di atasi pemerintah hal ini tercermin dari angka kemiskinan dan pengangguran yang masih ada dan belum pada level yang rendah. Sektor pertanian walaupun berperan besar terhadap pendapatan nasional tapi belum mampu menanggulangi masalah kemiskinan dan 
pengangguran sehingga perlu pergeseran atau transformasi ekonomi ke sektor lain seperti industri tetapi bukan berarti meninggalkan sektor pertanian namun bagaiman pertanian dapat meningkat produktifitasnya dengan mengadopsi perkembangan teknologi dan alokasi sumber daya manusia yang optimal.

\section{DAFTAR PUSTAKA}

Alkatiri, Lutfi.(2006) Analisa Pengaruh Foreign Direct Investment (FDI) dan Ekspor Terhadap Pertumbuhan Ekonomi. CIDES.

Appleyard, Dennis.;Alfred J field.;Jr. Steven L Cobb.(2008). International Economics. 6th Edition. McGraww-Hill.

Arsana, I Gede Putra.(2008). Modul VAR With Eviews 4. Ilmu Ekonomi FEUI. 2008

Asian Development Bank.(2009). Key Indicators For Asia and Pasific 2008. Asian Development Bank Statistics.

Balasubramanyam, V.N, M. Salisu, dan David Sapsford.(1996).Foreign Direct Investment and Growth in EP dan IS Countries. The Economics Journal, Vol. 106, No. 434, pp. 92-105. 1996.

Bank Indonesia.(2008). Laporan Perekonomian Indonesia Tahun 2008. Jakarta.

Bank Indonesia.(2013). Laporan Perekonomian Indonesia Tahun 2013. Jakarta.

Blanchard, Olivier.(2003). Macroeconomics.3rd Edition. Prentice-Hall.

Carkovic, Maria.;Ross Levine.(2002). Does Foreign Direct Investment Accelerate Economic Growth?. University of Minnesota.

De Mello, Luiz R.(1999). Impact of Foreign Direct Investment and Trade on Economic Growth. Oxford Economics Papers 51, 133-151. Oxford University Press.

Dornbusch, Rudiger.;Stanley,Fischer.;Richard,Startz.(2004). Macroeconomics. $\quad 9^{\text {th }}$ Edition. McGraww-Hill.

Dritsaki, Melina.;Chaido,Dritsaki.;Antonios,Adamo poulos.(2004).American Journal of Applied Sciences 1 (3) 230-235.

Enders, Walter. (2004). Applied Econometric Time Series. Wiley Series in Probability and Statistics.

Euphrasia,Susy.;Suhendra.(2004).Peranan Sektor Pertanian Dalam Pertumbuhan Ekonomi DI Indonesia Dengan Pendekatan Input-Output.

Gaspersz,Vincent.(1997).Manajemen Kualitas Penerapan Konsep-Konsep Kualitas Dalam Manajemen Bisnis Total. Jakarta: PT. Gramedia Pustaka Utama

Gujarati,Damodar N.(2004). Basic Econometrics. 4th Edition. McGraw-Hill. International Financial Statistics.(2008).CD-ROM. IMF.

Gumilar Wijaksana.; Muhammad Safri.; Parmadi. (2017).Kontribusi dan Elastisitas Subsektor dalam Sektor Pertanian di Kabupaten Tebo. Jurnal Paradigma Ekonomika, 12(2); 77-86.

Hardiani,H; Junaidi,J. (2011). Analisis Kuantitas dan Kualitas Penduduk sebagai Orientasi Pembangunan di Provinsi Jambi. Laporan Penelitian. Kerjasama BKKBN dengan PSK UNJA. Jambi

Mankiw, George N.(2001). Macroeconomics. 5th Edition. McGraw-Hill.

Marius, Jelamu,Ardu. (2004). Memecahkan Masalah Pengangguran di Indonesia, Makalah, IPB.

Pitartono.(2012). Analisis Tingkat Pengangguran Di Jawa Tengah Tahun 1997-2013. Skripsi S1, Program Sarjana Fakultas Ekonomika dan Bisnis Universitas Diponegoro Tahun 2012 
Ropingi.;Dany Artanto. (2002). Peranan Sektor Pertanian dalam Pengembangan Perekonomian Wilayah Propinsi Jawa Tengah (Pendekatan Analisis Input Output).Jurnal Ekonomi Pembangunan, 3(2); 157-172

Roy, Atrayee Ghosh.;Hendrik F Van Den Berg.(2006). Foreign Direct Investment and Economics Growth: A Time-Series Approach. Global Economy Journal, 6(1); 121

Salvatore, Dominic.(2007). International Economics. Prentice-Hall.

Sims, Christopher A.(1980). Macroeconomics and Reality. Econometrica, 48(1); 1-48

Umiyati.,Etik.;Amril.;Zulfanetti.(2017).Pengaruh Belanja Modal, Pertumbuhan Ekonomi dan Jumlah Penduduk Miskin terhadap Indeks Pembangunan Manusia di Kabupaten/kota Provinsi Jambi.Jurnal Sains Sosio Humaniora, $1(1) ; 29-37$

UNCTAD. (1998).World Investment Report 1998:Trends and Determinants. UNCTAD. UNCTAD.(2008).World Investment Report 2013: Transnational Corporations and The Infrastructure Challenge. UNCTAD. 